\title{
Adverse Impact of Sanctions on Control of COVID-19 Epidemic in Iran
}

\author{
Akbar Nikpajouh, MD, MPH'; Mohammad Sadegh Ahadi, MSc ${ }^{2}$ \\ ${ }^{1}$ Community and preventive medicine, Rajaie Cardiovascular Medical and Research Center, Iran University of Medical Sciences, Tehran, Iran \\ ${ }^{2}$ National Consultant on Green Climate Fund (GCF) Readiness Project in Iran, Department of Environment, Bureau for National Designated \\ Authority (NDA), Tehran, Iran
}

\section{Introduction}

According to official statistics, Iran stands among the 10 leading countries in terms of infection rate with over 93657 affected cases based on positive PCR test and 5957 deaths caused by COVID-19 up to April 30, 2020 based on information available at https://www.worldometers. info/coronavirus/.

According to the Charter of Human Rights (Secondary Rights) ${ }^{2}$ and International Health Regulations (2005), ${ }^{3}$ given the pandemic nature of COVID-19, announced by the World Health Organization (WHO) on March 11, $2020,{ }^{4}$ there is a need for cooperation of all countries to control this pandemic.

According to WHO regulations and the Charter of Human Rights, this question is raised, "is it possible for a country which is under the hardest possible economic sanctions to provide scientific recommendations to control COVID-19 in the short and medium-term?"

We know that control of COVID-19 focuses more on preventive measures such as reducing traffic, staying home, physical distancing, and quarantine, as no vaccine and the effective drug has yet been discovered for it.

Also, performing more and more diagnostic tests and treating more severe cases in the hospital with respiratory support are among the WHO recommendations.

Given what was stated above, the control and treatment of COVID-19 disease impose both direct and indirect socioeconomic costs that require government support packages. These costs include:

- Direct costs; including diagnosis, screening, hospitalization, and treatment,

- Indirect prevention costs; including providing essential supplies and health items for the elderly and those in quarantined cities,

- The economic costs imposed as a result of the closure of businesses, especially in the tourism sectors, hotels, transport, retail, etc,

- The socio-economic costs caused due to closure of educational places, social consequences of staying home, isolation, quarantine, and the psychological consequences caused by them. Taking preventive measures, treatment, and reducing socioeconomic consequences caused by COVID-19 epidemic require funding for direct medical costs and supportive packages to reduce indirect adverse effects, which require government funding.

Therefore, the economic sanctions would act as a large barrier against effective preventive scientific recommendations for the control of the COVID-19 pandemic.

Does the Control of the COVID-19 Pandemic in Iran Need Only Drugs, and Diagnostic and Therapeutic Medical Equipment?

This pandemic requires physical distancing and closure of many economic activities, and meanwhile, the Iranian government must help people economically and provide food and health items to encourage them to stay home and maintain physical distance. Also, during this period, due to the closure of businesses, sources of government revenue, including taxation, government services, and domestic sales of energy and electricity have decreased dramatically, while production and current costs of the public sector and private businesses continue. Besides, the direct costs of preventing, screening, controlling, and treating the disease are under the responsibility of the government.

Hence, the continued sanctions create several problems for providing necessary financial sources and transferring them to meet these requirements and accelerate the purchase and import of medical and diagnostic medical items, which ultimately make it difficult to control this disease in Iran.

If We Assume That Iran Is not Under Sanctions with Drugs and Medical Equipment, does it Mean That There Is no Problem in Supplying Drugs and Medical Equipment to Control COVID-19 and Other Diseases? Financial resources are needed for every purchase, including drugs and medical equipment. Thus, economic sanctions for any country whose foreign exchange earnings largely 
depend on the money from exporting oil, petrochemical products, and petroleum, will cause serious problems in purchasing drugs and medical equipment. This problem is bilateral, as the export of oil and its sub-products has been reduced due to sanctions and the price of oil has fallen below $\$ 20$ a barrel as a result of shocks and the sharp decline in demand due to the COVID-19 pandemic. $^{5}$

As a result, Iran's foreign exchange earnings have declined exponentially.

\section{Is Epidemic Control Necessary in Iran to Control the Global Pandemic?}

The answer is yes. All of us are living in a global village and all countries must do their best to control the epidemic in Iran and control its global pandemic.

\section{Are Money and Resources Needed to Control the Epidemic in Iran?}

The answer is yes. All countries have allocated high budgets to the private sector, staff, and people during quarantine and physical distancing. Also, resource sufficiency is a major issue for the Iranian government due to continued sanctions, a sharp drop in oil prices, and the impossibility of exporting petrochemical products. Sanctions have directly targeted human rights goals. For example, the United States has allocated $\$ 2000$ billion for compensating the losses caused by COVID- $9 .^{6}$

The German government has considered a $€ 156$ billion package to cope with the consequences of coronavirus. ${ }^{7}$

In coclusion it seems that COVID-19 makes our lives more dependent on each other than ever before, as this disease has spread to all countries in the shortest possible time. Therefore, all countries must cooperate to control this disease. Funding during this period is a major necessity for implementing physical distancing, staying at home, quarantine policies, providing drugs, and medical diagnostic equipment.

Continuous economic sanctions are a major barrier for the necessary funding to take preventive and control measures, such as continuing physical distancing with the closure of businesses, reducing traffic and providing essential health care to the elderly people, and implementing the quarantine policy.

Given the importance of epidemic control in all countries to succeed in controlling the global pandemic, there is a need to remove the economic sanctions for funding the implementation of direct control, prevention, treatment, and indirect measures such as the provision of supportive packages to continue physical distancing policies in Iran.
In this critical period, any reduction in Iran's sources of income as a result of sanctions will directly affect people's lives and health, which is contrary to the Charter of Human Rights.

Hence, it is Recommended:

- Removing the economic sanctions as the human impact of the sanctions is manifested in the COVID-19 epidemic,

- To establish special credit lines for the purchase of drugs and medical equipment required to control COVID-19 through international funds,

- Releasing the blocked Iranian money by foreign banks,

- Support of European and American countries for Iran to receive financial assistance and loans from international funds to cope with the adverse impact of the COVID-19 epidemic.

\section{Authors' Contribution}

All authors contributed to writing the article and approved the final format.

\section{Conflict of Interest Disclosures}

The authors declare no competing interests.

\section{Ethical Statement}

Not applicable.

\section{References}

1. WHO. Coronavirus disease 2019 (COVID-19) Situation Report -101.30 April 2020. Available from: https://www.who.int/docs/ default-source/coronaviruse/situation-reports/20200430sitrep-101-covid-19.pdf?sfvrsn=2ba4e093_2.

2. UN General Assembly, International Covenant on Economic, Social and Cultural Rights, United Nations, Treaty Series. 1966. vol. 993, p. 3. Available from: https://www.refworld. org/docid/3ae6b36c0.html. Accessed 4 September 2020.

3. WHO. International Health Regulation (2005), Toolkit for implementation in national legislation. Available from: https://www.who.int/ihr/Toolkit_Legislative_Implementation. pdf?ua $=1$.

4. Whitworth J. COVID-19: a fast evolving pandemic. Trans R Soc Trop Med Hyg. 2020;114(4):241-8. doi: 10.1093/trstmh/ traa025.

5. Ajami R. Globalization, the Challenge of COVID-19 and Oil Price Uncertainty. J Asia Pac Bus. 2020;21(2):77-9. doi: 10.1080/10599231.2020.1745046.

6. USA.gov. Government Response to Coronavirus, COVID-19. Available from: https://www.usa.gov/coronavirus.

7. Federal Ministry of Finance. Combating the coronavirus: Germany adopts the largest assistance package in its history. Avalable from: https://www.bundesfinanzministerium. de/Content/EN/Standardartikel/Topics/Priority-Issues/ Corona/2020-03-25-combating-the-corona-virus.html. Accessed 1 April 2020 